\title{
森ビルに招ける中国プロジェクトへの取組みについて
}

片田和 範*

1.はじめに

昨年，上海に高さ $492 \mathrm{~m}$ の超高層複合ビル「上海環 球金融中心」(写真-1) が竣工しました。延べ床面積は 六本木七ルズ森タワーとほほ同じ約 38 万 $\mathrm{m}^{2}$ で, 当プ ロジェクトは弊社が手がけた中国における3 番目の開発 物件です。弊社は港区を中心に都市再開発事業, 不動産 貢貸，管理事業に加え，文化・芸術・タウンマネジメン 卜事業を展開する総合デベロッパーですが，これまでの 中国での経験を生かし，当プロジェクトに取り組みまし た。今回は，幣社の中国事業への取組み，特に「上海環 球金融中心」プロジェクトについて，その概要やデベロッ パーとしてプロジェクトのスケジュールや品質管理等を どのようにマネジメントしたのかについて, 中国の建設 事情も含めてご紹介させていただきます。

\section{2. 中国事業への取組み経緯}

弊社は上海の将来性への投資として 1993 年に中国進 出を決定しました。1994 年には海外事業を行う「フォ レストオーバーシーズ梀」老設立し，(1)大連「森茂大厦」 を1996 年に, (2)上海「HSBC タワー」を1998 年に竣 工させました。

このように, 中国において開発プロジェクトに取り組 むにあたり，森茂大厦（24階建て）－HSBC タワー（46 階建て）上建物規模についても段階的に経験を踏み，デ ベロッパーとしてのノウハウ（企画立案から事業性の検 討, 施設計画, 資金調達, 行政折衝, プロジェクトスケ ジュール管理, 予算管理, 設計者・施工者等の選定, 設 計・監理, 品質管理, 契約管理等に加え, テナント誘致, 施設の管理・運営等）在積み重ね，今回の「上海環球金 融中心」 101 階建てに挑戦しました。「上海環球金融中 心」は垂直庭園都市という弊社コンセプトのもと，オフィ ス・ホテル・展望台・カンファレンス・商業施設等の各 種施設老備えた複合開発事業で, 中国経済の毫引役之し て発展目覚しい上海市浦東新区のなかでも国際的金融機 関の集積する陸家嘴金融貿易区のランドマークとなって います。1997 年 8 月に着工し, 1998 年 10 月に杭工事を 完了したものの, アジア通貨危機の影響などで工事は 4 年間の中断の後, 延べ面積や建物高さ, 階数など建物規 * かただ・かずのり/森ビル俶都市開発事業本部 什入統括部 部長

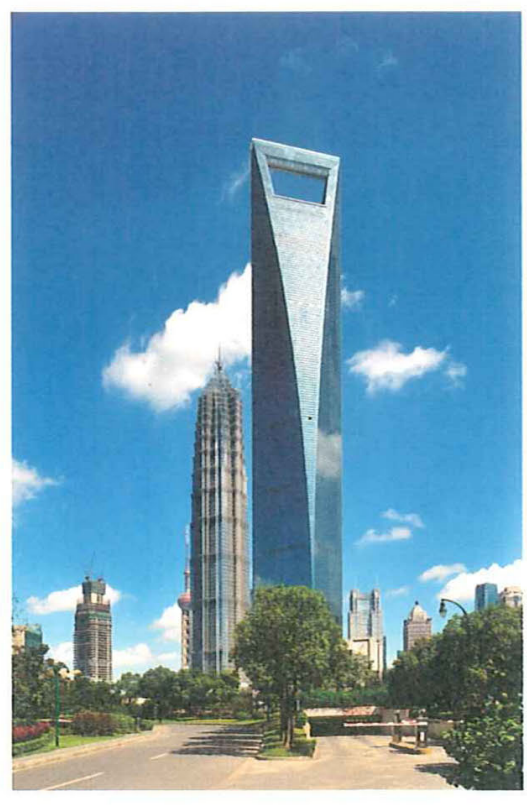

写真-1 上海環球金融中心（所在地; 中 国上海市浦東新区世紀大道 100 号)

表-1 弊社中国プロジェクトの実績

\begin{tabular}{|c|c|c|}
\hline 建物名称 & (1) 森茂大厦 & (2) HSBC タワー- \\
\hline 主用途 & 事枒所 & 事拐所 \\
\hline 延林面積 & $46401 \mathrm{~m}^{2}$ & $116824 \mathrm{~m}^{2}$ \\
\hline 構造種别 & SRC 造 & $\mathrm{SRC}$ 造 \\
\hline 階 数 & $\begin{array}{l}\text { 地上: } 24 \text { 階 } \\
\text { 地下 } 2 \text { 階 }\end{array}$ & $\begin{array}{l}\text { 地上 } 46 \text { 階 } \\
\text { 地下 } 4 \text { 階 }\end{array}$ \\
\hline 設 部 & $\begin{array}{c}\text { 森ビル } \\
\text { 大林組 } \\
\text { 中国東北建築設設研究院 }\end{array}$ & $\begin{array}{c}\text { 森ビル } \\
\text { フシタ・大林組 JV } \\
\text { 華東建筑設䚺研究院 }\end{array}$ \\
\hline 施 工. & 大林組 & フシタ・大林組 JV \\
\hline
\end{tabular}

模を拡大し， 2003 年に再着工しました。2008 年の竣工 までは 1994 年の着想から実に 14 年間にわたるプロジェ クトでした。

3. 中国の建設事情（資質制度と請負制限）

日本においては一定規模以上の建設工事を請負う者は 国土交通大臣または都道府県知事の建設業許可を受けな ければなりません。中国においても同様の制度として建 設業の営業許可があります。以前は外国の建設会社が中 国で建設工事在行うに際し，独資企業では営業許可を取 得できず，中国企業上の合弁会社を中国に設立し，必要 
表-2 総合請負業資質（2003 調查時点）

\begin{tabular}{|c|c|c|c|c|c|c|c|c|c|c|}
\hline & \multicolumn{5}{|c|}{ 請負工事可能範囲 } & \multicolumn{5}{|c|}{ 資質收得条件 } \\
\hline & 請負金額 & 階 数 & スパン & 高 さ & $\begin{array}{l}\text { 面 皘 } \\
\text { 建物群 }\end{array}$ & 資本金 & 純資産 & $\begin{array}{l}\text { 年間施工実綪· } \\
\text { 過去 } 3 \text { 年の平均 } \\
\text { 年間売上 }\end{array}$ & 従業員 & 技術采侻業員 \\
\hline 特 級 & \multicolumn{5}{|c|}{ 制限なし } & $\begin{array}{c}3 \text { 億元 } \\
\text { (45 億円) } \\
\text { 以上 }\end{array}$ & $\begin{array}{l}3.6 \text { 億元 } \\
\text { (54 億円) } \\
\text { 以上 }\end{array}$ & $\begin{array}{c}15 \text { 億元 } \\
\text { (225 億円) } \\
\text { 以上 }\end{array}$ & \multirow{2}{*}{300 人以上 } & \multirow{2}{*}{$\begin{array}{c}200 \text { 人以上 } \\
\text { ただし } \\
\text { 高級 }=10 \text { 人以上 } \\
\text { 中級 }=60 \text { 人以上 }\end{array}$} \\
\hline 一級 & \multirow{3}{*}{$\begin{array}{l}\text { 資本金の } \\
5 \text { 倍以下 }\end{array}$} & $40 \mathrm{~F}$ 以下 & 制限なし & $240 \mathrm{M}$ 以下 & 20 万 $\mathrm{m}^{2}$ 以下 & $\begin{array}{c}5000 \text { 万元 } \\
(7.5 \text { 億円 }) \\
\text { 以上 }\end{array}$ & $\begin{array}{c}6000 \text { 万元 } \\
\text { (9 億円) } \\
\text { 以上 }\end{array}$ & $\begin{array}{c}2 \text { 億元 } \\
\text { (30 億円) } \\
\text { 以上 }\end{array}$ & & \\
\hline 二 級 & & $28 \mathrm{~F}$ 以下 & $36 \mathrm{M}$ 以下 & $120 \mathrm{M}$ 以下 & 12 万 $\mathrm{m}^{2}$ 以下 & $\begin{array}{c}2000 \text { 万元 } \\
\text { (3 億円) } \\
\text { 以上 }\end{array}$ & $\begin{array}{l}2500 \text { 万元 } \\
\text { (3. } 8 \text { 億円) } \\
\text { 以上 }\end{array}$ & $\begin{array}{c}8000 \text { 万元 } \\
\text { (12 億円) } \\
\text { 以上 }\end{array}$ & 150 人以上 & $\begin{array}{c}100 \text { 人以上 } \\
\text { 高級 }=2 \text { 人以上 } \\
\text { 中級 }=20 \text { 人以上 }\end{array}$ \\
\hline 三級 & & $14 \mathrm{~F}$ 以下 & $24 \mathrm{M}$ 以下 & $70 \mathrm{M}$ 以下 & 6 万 $\mathrm{m}^{2}$ 以下 & $\begin{array}{c}600 \text { 万元 } \\
\text { (9000 万円) } \\
\text { 以上 }\end{array}$ & $\begin{array}{c}700 \text { 万元 } \\
\text { (1 億円) } \\
\text { 以上 }\end{array}$ & $\begin{array}{c}2400 \text { 万元 } \\
(3.6 \text { 億円) } \\
\text { 以上 }\end{array}$ & 50 人以上 & $\begin{array}{c}30 \text { 人以上: } \\
\text { 中級 }=10 \text { 人以上: }\end{array}$ \\
\hline
\end{tabular}

な営業許可証を取得する必要がありました。ただし，特 定のプロジェクトに限ってプロジェクト単位で臨時の営 業許可を得る手法（通称“ワンプロ”）があり，日系ゼ ネコンを含め多くの外国企業はこの「プロジェクト単位 の臨時営業許可」での施工実績を残してきました。元請 会社が日系ゼネコンであっても, 専門工事業者（以下， サブコンと呼ぶ）はローカル企業を使うことが一般的で あり，その関係の中で中国企業が外国企業の進んだ建設 関連の技術や施工管理手法を学ぶことができました。 2003 年この“ワンプロ”制度が廃止され，外国企業に も独資での現地会社設立の道が開けました。

一方，外国企業も中国企業之同じ資格制度の適用索受 けることになり，表-2のように建設会社は企業の資本 金, 純資産, 売上げ実績, 従業員数等により資質が設定 され，その請負工事範囲が制限されることとなりました。

ちなみに日系ゼネコンは2008 年堼点でむ「一級」ま でであり，資本金 3 億元（45 億円)，従業員 300 人をク リアするための資金を投入してまで「特級」を取得しよ うという日系ゼネコンは今のところいません。このよう な背景があり，大連「森茂大夏」と上海「HSBC タワー」 はともに“ワンプロ”として日系ゼネコンに施工を依頼 しましたが，再着工が“ワンプロ”廃止後となった「上 海環球金融中心」の元請会社には「特級」資質が必要之 なり，「特級」を有する中国の建設会社の中から高層建 築の実績が多数ある二大建設会社である中国建築工程総 公司と上海建工 (集时) 総公司を採用することになりま した（表-3）。なお，表-2 は総合請負業資質の例ですが, 専門工事会社（鉄骨・外装・内装・設備工事等）にも同 様な資質等級があり，2003 年時点中国全土で総合請負 業者 30000 社以上, 専門工事会社（鉄骨・外装・内装・ 設備工事等) 30000 社以上が登録されていました。

また，施工者選定についても制度があり，例えば建設 会社選定における入札に関しては各地方政府の建設委員 会番下に「入札管理弁公室」があり, 公平な入札が行わ れているかを管理しています。施主が外資である場合に
表-3 元請会社（メインコン）

\begin{tabular}{l|c|c}
\hline \multicolumn{1}{c|}{2003 年時点 } & 中国建築上程総公司 & 上海建工 (集団) 総公司 \\
\hline 本社所在地 & 北京市 & 上海市 \\
\hline 資本金 & 603 億円 & 134 億円 \\
\hline 壳上高 & 8458 億円 & 1843 億円 \\
\hline 従業員数 & 122500 名 & 50000 名 \\
\hline
\end{tabular}

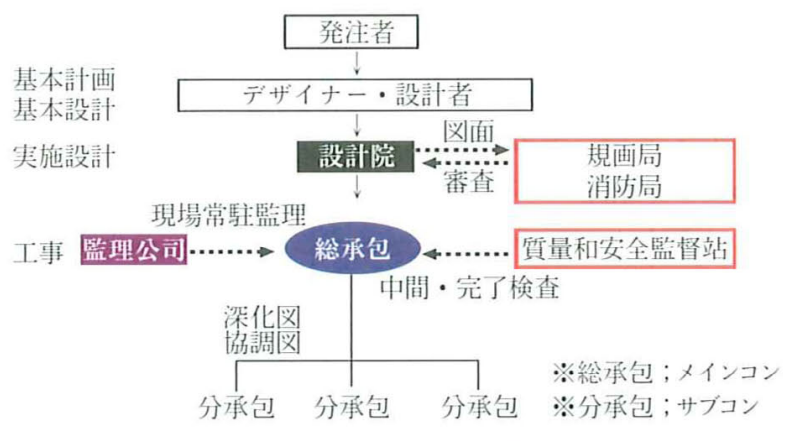

図-1建築生産体制

は入札免除の特例を受けられるケースがあり，本プロジェ クトはその特例を受け，「特級」資質を有する複数の施 工会社の中から総合評価方式にて前述の 2 社を選定しま した。ただし外資の発注者であっても工事着工に際して は中国において総承包上呼ばれる元請（以下，メインコ ンと呼ぶ）との工事請負契約書を添えて地方政府の建設 委員会に届出が必要となります。参考までに図-1に本 プロジェクトの建築生産体制の概略を示します。

\section{4.「上海環球金融中心」プロジェクト概要}

\section{1 建物概要・建物用途}

敷地面積 ; $30000 \mathrm{~m}^{2}$ 建築面積 ; $14400 \mathrm{~m}^{2}$ 延床面積; $381600 \mathrm{~m}^{2}$ 階数 ; 地上 101 階, 地下 3 階 構造； RC, SRC, S 造 総事業費; 約 1250 億门 97-100 F ; 展望台９4 F ；スカイアリーナ 79-93 F ; ホテル 28-29F；メディアセンター 7-77 F ; オフィス 3-5 F ; フォーラム B 3-3 F ; ショップ, レストラン, 駐車場 


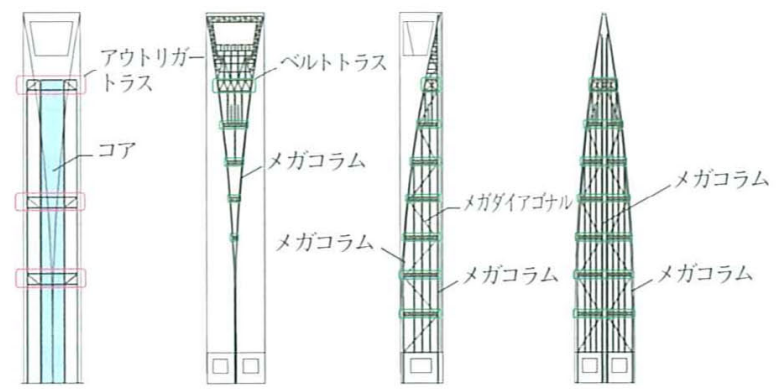

図-2＼cjkstart構造システム概念図

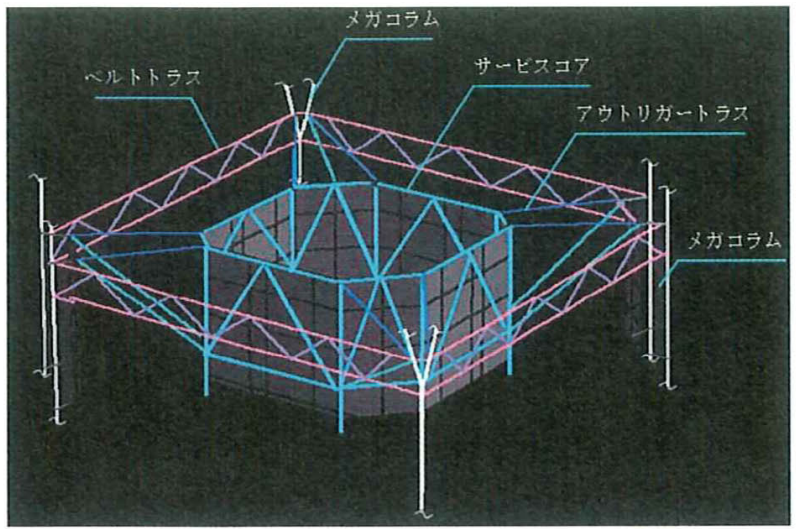

図-3＼cjkstart構造システム概要

\section{2 構 造 概 要}

建物の外壁は主にアルミカーテンウォール（倍強度ガ ラス）ですが，構造的には，外周部の柱・梁・ブレース からなる「外周メガストラクチャー」と中央の「コアウォー ル」を配した二重チューブ構造を採用し, 双方の構造休 を連結する「アウトリガー」による 3 つのシステムの組 合せにより，地震や強風に対し極めて高い安全性を確保 しました。鉛直荷重は，コア内部のトラスとベルトトラ スを介して，12 層ごとにメガコラムとコアウォール （コンクリートは中国基準 C 40～C 60 を使用；“C”はキュー ビック強度）に移行させています（図-2, 図-3）。

\section{5. プロジェクトの管理体制}

まず設計体制ですが，設計には内装・照明・サイン・ ランドスケープ等を含め, 国内外 17 社の設計事務所・ デザイナーが参画しましたが，基本的には表-4のよう な体制にて当社設計部が全体の監修を行いました。

ところで，工事監理に関しては中国特有の制度があり， 蛧-1に記載がある「監理公司」とは，施工者の作成し た躯体図・設備図・製作図・施工計画書等を審查し，現 場および工場における検查老実施し, 施工四通りに品質 が保たれているかを監督・指導しています。また, 設計 変更等が法規に合致したものかどうかの審査も行います。 設計者が監理者を兼ねることはできず，監理公司は発注 者との直接契約となります。

次に発注体制ですが, 弊社の仕入統括部を中心に発注 体制を構築し，企画段階一設計段階における設計事務所 やコンサルタント等への業務委託の発注業務, 工事発注
表-4 設計体制

\begin{tabular}{|c|c|c|c|}
\hline & 建 築 & 構 造 & 設 備 \\
\hline \multirow{3}{*}{$\begin{array}{l}\text { 基本 } \\
\text { 設計 }\end{array}$} & \multicolumn{3}{|c|}{ 森ビル(榬一級建築事務所 } \\
\hline & KPF & LERA & 建筑設借設計研究所 \\
\hline & $\begin{array}{c}\text { Kohn Pedersen Fox } \\
\text { Associates P.C. }\end{array}$ & $\begin{array}{l}\text { Leslie E.. Robertson } \\
\text { associates R.L..L.P. }\end{array}$ & \\
\hline \multirow{2}{*}{$\begin{array}{l}\text { 奏施 } \\
\text { 設計 }\end{array}$} & 入江三宅設計事務所 & 構造計画研究所 & 建築設借設計研究所 \\
\hline & \multicolumn{3}{|c|}{ 上海現代建筑設計（集団）有限公司/華東建築設計研究院有限公司 } \\
\hline
\end{tabular}

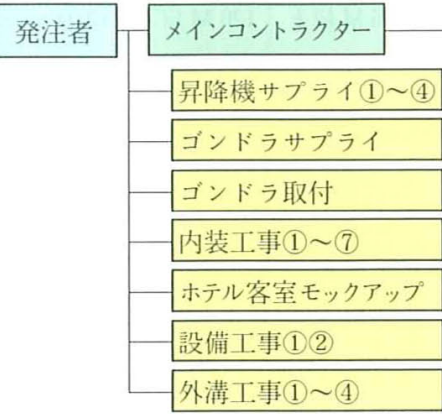

ノミネーテッドサプコントラクター

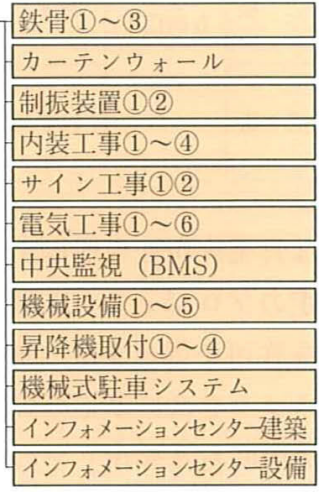

図-4 工事発注区分

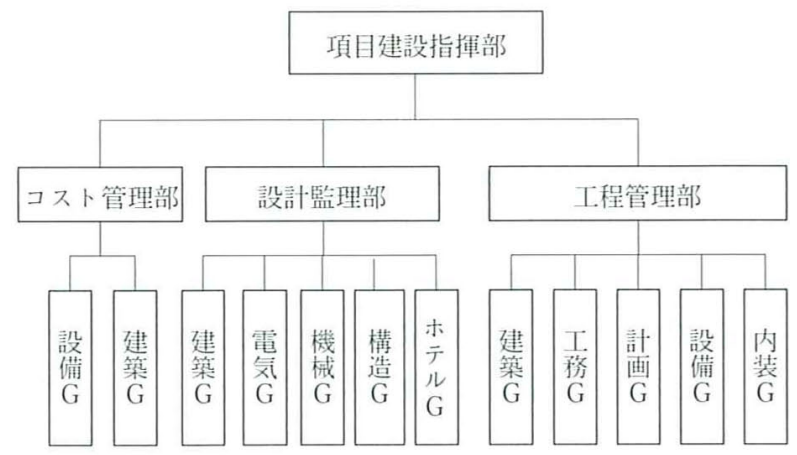

図-5 現場 CM 体制

段階における施工者・サプライヤー等選定業務に対応し ました。当プロジェクトは設計/施工分離, 設計者・コ ンサルタントとは業務委託契約, 工事は指定下請けを含 むメインコン一括発注方式に一部直発注工事としました (図-4)。メインコンとの契約は総価請負契約で契約約款 はFIDIC に約款修正条項を加えたものを使用しました。

当社はプロジェクト全体を通して事業主という立場か らプロジェクトマネージメントを行う一方, 上海環球金 融中心有限公司から設計監理・工事監理・工事契約管理 業務等を含む CM（コンストラクション・マネジメント） 業務を受託し，工事段階においては図-5に示すように， 弊社社員を中心に日采企業加の建築技術者や現地採用 スタッフを加えた約 90 名の現地組織を組成し, 特に建 設工事における「品質管理」「スケジュール管理」「コス 卜管理」「安全管理」「契約管理」等を行いました。

工事期間中は設計調整や監理，施工運営老门滑にする ために，上記 CM チームに加え，中国の監理公司や設 
計院の担当者が現場に常駐する体制を整えました。

どの管理む決して容易ではありませんでしたが, 特に 「品質管理」は工事発注段階からの大きな課題のひとつ でした。というのも,これまでの 2 物件はどちらも元請 会社は日系ゼネコンであり, 当該ゼネコンとは日本国内 での取引実績むあったため, 幣社の要求する品質水準へ の共通認識を確認することができていました。しかし当 プロジェクトは弊社によっても中国メインコンが元請と なる初めてのケースであり, 幣社の要求する品質水準を いかに正確に施工者に伝えるかが課題のひとつでした。 そこで, 元請工事の入札参加業者には六本木ヒルズ等の 弊社の建物老入札前に見学してもらい, 施工品質の事前 確認を行ったうえで応札してもらうという過程を踏みま した。また, 各専門工事の品質確保を目的として, 製品 品質や施工品質に実績のあるメーカーや施工者圭中心に 専門工事業者等を指定する指定サブコン方式をとりまし た(図-4)。

さらに，ホテル客室に関しては，まず日系ゼネコンに てモデルルームを施工し, 次にホテル客室内装工事の入 札参加業者には応札前にこのモデルルームを見学させる ことで要求する品質水準を伝えました。このモデルルー ムは実際の客室の施工中も品質確認のためにいくたびと なく利用しました。また，オフィス内装工事もまず先行 ルームにて施工品質の確認をし, その後全フロアーの内 装工事に着手するというスッテプを踏みました。その他, 施主直発注の第三者機関による検查（例えば鋼材の抜取
検査, 鉄骨溶接部の検査) 等による品質確認を行いまし た。このような品質確保への取組みなしには, 建物の完 成はなかったかもしれません。

6. まと め

日本と中国の環境や法制度の違い等によりプロジェク トの進め方も違ってきますが, 中国の制度をうまく利用 できた例として，スケジュールに関しては，ファストト ラック（段階施工方式）による全体スケジュールの短縮 が上げられます。当プロジェクトは地下工事の着工許可 と地上工事の着工許可を段階的に取得しました。つまり, 地下部分の実施設計完了後に地下工事に着手し, 地下工 事老行っている間に地上部分の実施設計老行うことで, 設計と施工を合わせた全体工期を短縮できました。日本 の確認申請制度にはなじまない手法ですが, 長期間にわ たるプロジェクトにおいては非常に効率的な手法である と感じました。

このプロジェクトを通じて, 個人的には中国の建築関 係者から本当に多くのことを学びました。確かに日本の 建築技術が中国の建築技術より勝っている点はあります が，現場での職人の動員力や各種規制に対する柔軟さに おいては感心することが多々ありました。日本と中国が お互いの良いところを学びあうことで, 今後の雨国の建 設技術がますます発展し, 双方の事業が拡大することを 期待しています。 